\begin{tabular}{|l|l|l||}
\hline \multicolumn{2}{|c|}{ PublisherInfo } \\
\hline \hline PublisherName & $:$ & BioMed Central \\
\hline \hline PublisherLocation & $:$ & London \\
\hline \hline PublisherImprintName & $:$ & BioMed Central \\
\hline \hline
\end{tabular}

\title{
Placental imprinting
}

\begin{tabular}{|l|c|l||}
\hline \multicolumn{2}{|c|}{ ArticleInfo } \\
\hline \hline ArticleID & $:$ & 4517 \\
\hline \hline ArticleDOI & $:$ & $10.1186 /$ gb-spotlight-20020628-03 \\
\hline \hline ArticleCitationID & $:$ & spotlight-20020628-03 \\
\hline \hline ArticleSequenceNumber & $:$ & 183 \\
\hline \hline ArticleCategory & $:$ & Research news \\
\hline ArticleFirstPage & $:$ & 1 \\
\hline \hline ArticleLastPage & $:$ & 2 \\
\hline \hline & & RegistrationDate : 2002-6-28 \\
\hline ArticleHistory & $:$ & OnlineDate \\
\hline \hline ArticleCopyright & $:$ & BioMed Central Ltd2002-6-28 \\
\hline \hline ArticleGrants & $:$ & \\
\hline \hline ArticleContext & $:$ & 130593311 \\
\hline \hline
\end{tabular}




\section{Jonathan B Weitzman}

Email: jonathanweitzman@hotmail.com

Mammalian imprinted genes are expressed from only one parental chromosome, and many are involved in regulating placental and fetal growth. It has been hypothesized that paternal imprinted genes favour the growth of the fetus, while maternally expressed genes restrict fetal growth. In the June 27 Nature, Constancia et al. describe the role of the paternally expressed Igf2gene, encoding insulin-like growth factor II, in placental growth regulation (Nature 2002, 417:945-948). They generated mice with a deletion in an $I g f$ transcript that is expressed from a $\mathrm{P} 0$ promoter specific for the labryrinthine trophoblast cells of the placenta. Lack of the P0 transcript resulted in placental growth restriction from embryonic day 12 . This caused a decrease in passive permeability and nutrient transfer across the placenta, leading to subsequent reductions in fetal growth.

\section{References}

1. Genomic imprinting: parental influence on the genome.

2. Nature, [http://www.nature.com]

3. Parental imprinting of the mouse insulin-like growth factor II gene. 